\title{
Geology of Los Azufres caldera, Mexico, and its relationships with regional tectonics
}

\author{
L. Ferrari, V.H. Garduño, G. Pasquarè and A. Tibaldi \\ Dipartimento di Scienze della Terra, Università di Milano, Via Mangiagalli 34, 20133 Milano, Italy
}

(Received February 28, 1990; revised version accepted October 23, 1990)

\begin{abstract}
Ferrari, L., Garduño. V.H., Pasquarè, G. and Tibaldi, A., 1991. Geology of Los Azufres caldera, Mexico, and its relationships with regional tectonics. In: S.P. Verma (Editor), Calderas: Genesis, Structure and Unrest. J. Volcanol. Geotherm. Res., 47: $129-148$.

The Los Azufres geothermal field is one of several silicic centres of the Mexican Volcanic Belt (MVB) for which a caldera structure was suggested. Geological and structural surveys in a wide area surrounding Los Azufres reveal that this complex is situated in an area of unusual concentration of acid volcanism, consisting of four pyroclastic units and several dome complexes. Although a complete caldera structure is not morphologically evident, several facts suggest a long collapse history at Los A zufres:

- the geothermal field lies at the centre of a subcircular depressed area $(27 \times 26 \mathrm{~km}$ in size $)$ filled by a distinctive fluviolacustrine sequence;

- Middle to Late Miocene rocks bound to the south and to the north of this depression and are encountered only at depth inside it;

- four large ignimbritic suites of latest Miocene and Pliocene age outcrop outside the depression;

- volume estimations of these pyroclastic products are comparable with the missing volume of the depressed area;

- no alternative caldera structures exist in a radius of $200 \mathrm{~km}$ from Los Azufres;

- dacitic to rhyolitic lavas, principally extruded as dome complexes, were emplaced inside this depression during the Pleistocene.

Los Azufres is therefore interpreted as a nested caldera of latest Miocene and Pliocene age.

The recent regional tectonic evolution of the central sector of MVB comprises a Late Miocene-Early Pliocene left-lateral transcurrent phase, followed by a Late Pliocene-Quaternary transtensional one. The silicic volcanism occurring between 6.1 and 2.8 Ma can be linked to the first phase, while in the adjacent areas of MVB a volcanic hiatus can be recognized. The following transtensional phase reached the Los Azufres area only during the Pleistocene and disrupted the caldera structure. Normal faults, developed during this period, controlled the uprising of basic magma which partly interacted with the remaining differentiated one and produced part of the recent intracaldera cycle.
\end{abstract}

\section{Introduction}

The Los Azufres acid volcanic complex, known as an important geothermal field (Gutiérrez and Aumento, 1982), is located some $200 \mathrm{~km} \mathrm{WNW}$ of Mexico City, in the central sector of the Mexican Volcanic Belt (MVB) (Fig. 1). Unlike other silicic complexes of MVB (Verma, 1987), such as the Late
Pleistocene La Primavera (Mahood, 1980) and Los Humeros (Perez-Reynoso, 1978) or the Early Pliocene Amealco (Sanchez-R., 1978) and Huichapan (Demant, 1981) centres, no caldera structure was recognized at Los Azufres in earlier works on the volcanism of this area (Silva-Mora, 1979; Demant, 1981). In a more recent work (Pradal and Robin, 1985), the existence of a caldera struc- 
ture of Middle Pleistocene age was proposed in order to explain the acid activity at Los Azufres. The result of our geological and structural mapping combined with extensive $\mathrm{K}$-Ar dating in the Los Azufres area suggest a more complex geological scenario than the model proposed by Pradal and Robin (1985). As discussed in the final section, a clear caldera structure is not morphologically evident in the Los Azufres area. Nevertheless, the geothermal field is situated at the centre of a partly depressed area where the Middle to Late Miocene volcanic basement cropping out in the north and in the south is encountered only at depth of several hundreds of meters. Four large ignimbritic suites of latest Miocene and Pliocene age are exposed outside this area while during the Pleistocene large amounts of silicic domes were emplaced within it. These data suggest a complex collapse history and place the inception of silicic volcanism in the Los Azufres area well before the Pleistocene. Furthermore, new models of the tectonic evolution of MVB (Pasquarè et al., 1988; Ferrari et al., 1990) relate the silicic volcanism of Los Azufres to specific regional tectonic events. These relations and the presentation of new geological, geochronological and structural data, constitute the major focus of this work. Although many aspects of the geologic evolution of Los Azufres still remain to be clarified, our data provide some important constraints that are useful for further investigations in this area.

\section{Regional volcanic stratigraphy}

In order to investigate the geological and structural evolution of Los Azufres, we studied a larger area of the central sector of the MVB as represented in Figures 1 and 2. A detailed regional geological description of these areas is the subject of another paper (Pasquarè et al., in press a); in this paper we present a general account and concentrate ourselves on the Plio-Quaternary vol-

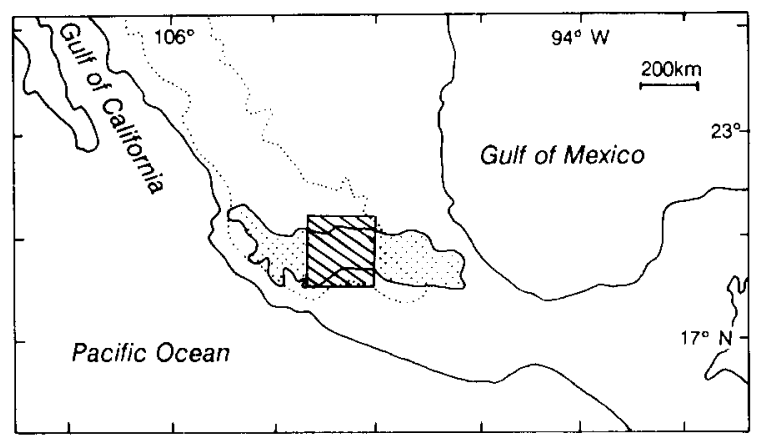

Fig. 1. Location of the study area (box). Dotted line limits the Sierra Madre Occidental. Continuous line limits the Mexican Volcanic Belt.

canic activity related to the Los Azufres centre. Eleven new K-Ar dates from geologic units of the Los Azufres area are listed in Table 1; other published radiometric age determinations relevant for the geology of the area are reported in Table 2 . These data provide a chronologic base for the volcanic stratigraphy of Los Azufres and adjoining areas. The various recognized ignimbritic suites were correlated with the more plausible source areas taking into account their age, their distribution and the paleomorphology of the time of emplacement. Further field work aiming at reconstructing isopach maps is in progress.

\section{Pre-Late Miocene units}

In the studied area, the Mesozoic and Eocene prevolcanic basement outcrops both in the north and in the south but it consists of different tectonostratigraphic assemblages. In the northern part of the area, sedimentary rocks of the Soyatal Fm., belonging to the Sierra Madre Oriental fold-thrust belt, outcrop at various sites north of Queretaro and Celaya (Fig. 2) (Pasquarè et al., in press). To the south, low-grade metamorphic sedimentary and volcano-sedimentary rocks of the Guerrero terrane (Campa and Coney, 1983) are exposed in the Tzitzio and Tlalpujahua areas, while near Zitácuaro the same rocks are thrusted on carbonate sequences bearing 
TABLE 1

New K-Ar age determinations in the Los Azufres Area

\begin{tabular}{|c|c|c|c|c|c|c|c|c|}
\hline Sample & $\begin{array}{l}\text { Long. } \\
(\mathrm{N})\end{array}$ & $\begin{array}{l}\text { Lat. } \\
\text { (W) }\end{array}$ & $\begin{array}{l}\text { Material } \\
\text { dated }\end{array}$ & $\begin{array}{l}\% \mathrm{~K} \\
\text { aver. }\end{array}$ & $\begin{array}{l}{ }^{40} \mathrm{Ar}^{*} \\
\left(\times 10^{-10} \mathrm{~mol} / \mathrm{g}\right)\end{array}$ & $\begin{array}{l}{ }^{40} \mathrm{Ar}^{*} \\
(\%)\end{array}$ & $\begin{array}{l}\text { Age } \\
(\mathrm{Ma})\end{array}$ & Error \\
\hline \multicolumn{9}{|c|}{ El Terrero Ignimbrite } \\
\hline $\mathrm{Mx} 88-19^{a}$ & 100.94 & 19.60 & Pl. & 0.90 & 0.096 & 31.0 & 6.12 & \pm 0.60 \\
\hline \multicolumn{9}{|c|}{ Siete Cruces and El Fraile dome complex } \\
\hline $\mathrm{Mx} 88-43^{\mathrm{a}}$ & 100.44 & 20.09 & San. & 6.02 & 0.568 & 33.0 & 5.45 & \pm 0.50 \\
\hline $\mathrm{Mx} 88-28^{: 4}$ & 100.47 & 19.63 & Bio. & 5.66 & 0.421 & 30.0 & 4.30 & \pm 0.30 \\
\hline \multicolumn{9}{|c|}{ Amealco Ignimbrite } \\
\hline $\mathrm{Mx} 88-22^{a}$ & 100.80 & 20.36 & $\mathrm{Pl}$. & 1.11 & 0.074 & 11.0 & 3.83 & \pm 0.40 \\
\hline \multicolumn{9}{|c|}{ Lake Cuitzeo Ignimbrite } \\
\hline Mor $4^{i}$ & 101.21 & 20.10 & San. & 3.02 & 2.162 & 61.0 & 2.80 & \pm 0.20 \\
\hline \multicolumn{9}{|c|}{ Zinapécuaro rhyolitic domes } \\
\hline $\operatorname{Ar} 5^{b}$ & 100.80 & 19.85 & WR & 4.36 & 0.112 & 6.1 & 1.53 & \pm 0.13 \\
\hline $\operatorname{Ar} 3^{b}$ & 100.85 & 19.85 & WR & 4.16 & 0.089 & 18.6 & 1.21 & \pm 0.04 \\
\hline $\operatorname{Ar} 4^{b}$ & 100.85 & 19.88 & WR & 3.85 & 0.081 & 7.0 & 1.19 & \pm 0.09 \\
\hline $\operatorname{Ar} 2^{b}$ & 100.71 & 19.81 & WR & 3.91 & 0.079 & 16.3 & 1.14 & \pm 0.04 \\
\hline \multicolumn{9}{|c|}{ Pleistocene basalts } \\
\hline $\operatorname{Mex} 211^{\mathrm{b}}$ & 101.72 & 19.83 & WR & 1.67 & 0.022 & 4.4 & 0.75 & \pm 0.15 \\
\hline $\operatorname{Mex} 219^{\mathrm{b}}$ & 101.75 & 19.88 & WR & 1.41 & 0.022 & 3.4 & 0.87 & \pm 0.17 \\
\hline
\end{tabular}

All K-Ar ages are standardized to the decay constants recommended by Steiger and Jäger (1977).

a Analyses performed at Instituto Mexicano del Petróleo, Mexico City, in 1986 and 1988.

${ }^{b}$ Analyses performed at Istituto di Geologia e Geofisica dell'Università di Napoli, Italy, in 1979.

$\mathrm{WR}=$ whole rock; $\mathrm{Pl} .=$ plagioclase San. = sanidine; $\mathrm{Bio} .=$ biotite; ${ }^{40} \mathrm{Ar}^{*}=$ radiogenic ${ }^{40} \mathrm{Ar}$.

TABLE 2

Selected published K-Ar dates of the Los Azufres area

\begin{tabular}{|c|c|c|c|c|c|c|c|}
\hline Sample & Rock type & $\begin{array}{l}\text { Long. } \\
(\mathrm{N})\end{array}$ & $\begin{array}{l}\text { Lat. } \\
\text { (W) }\end{array}$ & $\begin{array}{l}\text { Material } \\
\text { dated }\end{array}$ & $\begin{array}{l}\text { Age } \\
(\mathrm{Ma})\end{array}$ & Error & Source \\
\hline Ls 23 & Andesite & 100.91 & 19.65 & WR & 14.10 & \pm 0.70 & 1 \\
\hline $\mathrm{Az} 20^{*}(\mathrm{a})$ & Bas.-andesite & 100.68 & 19.75 & WR & 10.20 & \pm 0.60 & 2 \\
\hline $\mathrm{Az} 6^{*}(\mathrm{~b})$ & Andesite & 100.66 & 19.76 & WR & 5.00 & \pm 0.40 & 2 \\
\hline $\mathrm{Az} 20^{*}(\mathrm{c})$ & Dacite & 100.68 & 19.75 & WR & 3.10 & \pm 0.20 & 2 \\
\hline 443 & Rhyolite & 100.75 & 19.88 & WR & 1.60 & \pm 0.15 & 1 \\
\hline- & Rhyolite & 100.63 & 19.81 & WR & 1.03 & \pm 0.02 & 3 \\
\hline- & Andesite & 100.64 & 19.76 & glass & 1.03 & \pm 0.20 & 3 \\
\hline - & Rhyolite & 100.64 & 19.76 & WR & 0.93 & \pm 0.04 & 3 \\
\hline- & Rhyolite & 100.66 & 19.80 & glass & 0.84 & \pm 0.02 & 3 \\
\hline- & Dacite & 100.61 & 19.81 & Pl. & 0.33 & \pm 0.07 & 3 \\
\hline - & Rhyolite & 100.70 & 19.75 & Bio. & 0.30 & \pm 0.07 & 3 \\
\hline- & Rhyolite & 100.70 & 19.78 & Bio. & 0.15 & \pm 0.05 & 3 \\
\hline- & Rhyolite & 100.71 & 19.80 & glass & 0.14 & \pm 0.02 & 3 \\
\hline 452 & Rhyodacite & 100.38 & 19.53 & WR & 0.05 & \pm 0.03 & 1 \\
\hline
\end{tabular}

*Sample from geothermal wells: (a) depth of about $2700 \mathrm{~m}$; (b) depth of about $700 \mathrm{~m}$; (c) depth of about $800 \mathrm{~m}$. Sources: 1 - Nixon et al. (1987); 2 - Aumento and Gutiérrez (1980), in Dobson and Mahood (1985); 3 - Dobson and Mahood (1985). 


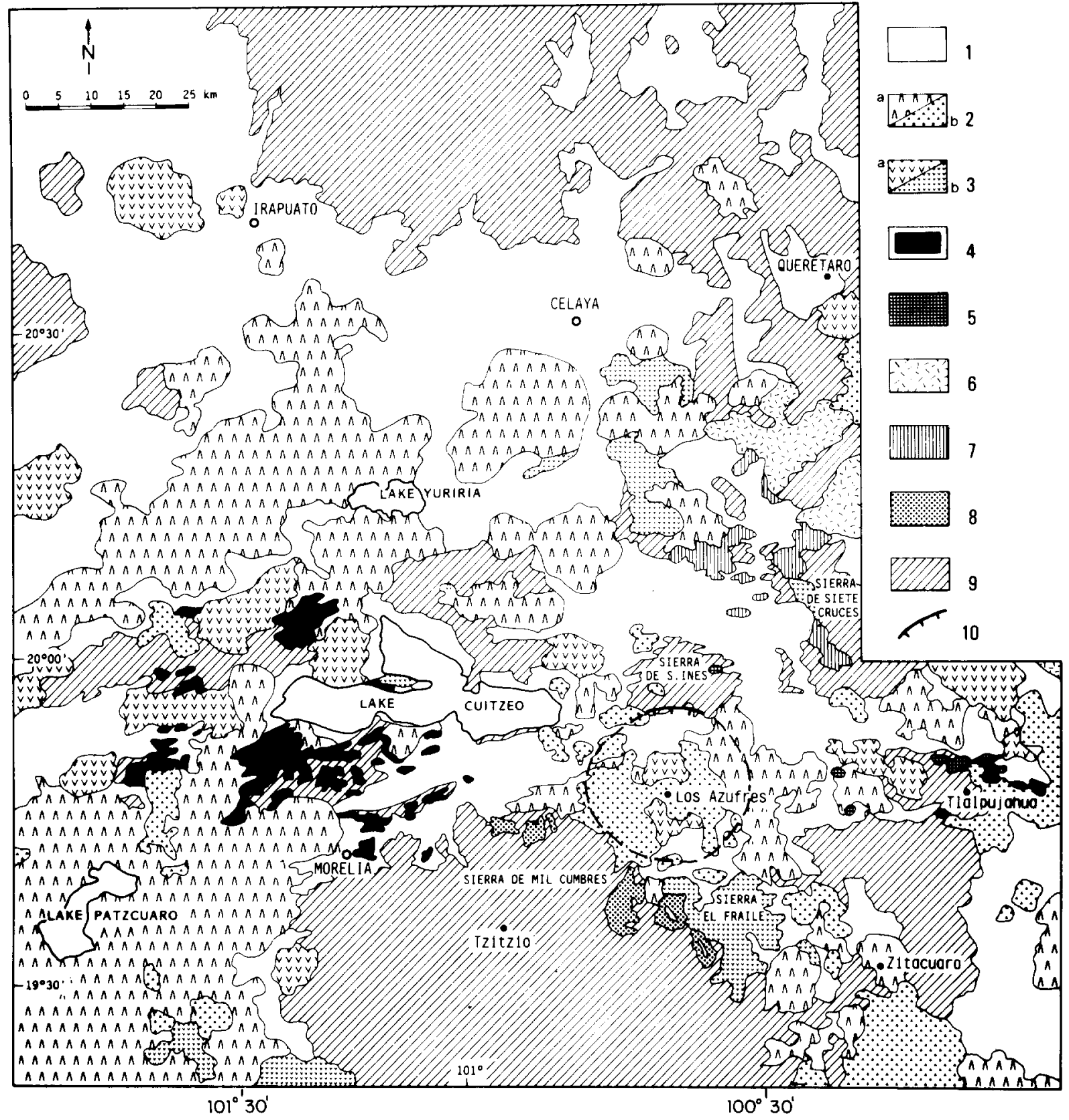

Fig. 2. Regional geologic sketch-map of the studied area. Dashed line encircles the Los Azufres total collapsed sector. $1=$ lacustrine sediments and alluvial deposits; 2 Quaternary volcanic rocks of the MVB: (a) basaltic to andesitic lava and cinder cones; (b) dacitic to rhyolitic domes; 3 = Pliocene volcanic rocks of the MVB: (a): basaltic to andesitic lava cones; (b) dacitic to rhyolitic domes; $4=$ Lake Cuitzeo ignimbrite; $5=$ Inés ignimbrite; $6=$ Amealco ignimbrite; $7=$ El Terrero ignimbrite; $8=$ Pucuato ignimbrite; $9=$ Pre-Pliocene geologic units; $10=$ outcropping caldera rim.

Tethian affinities (Israde and Martínez, 1986). In the south, these basement rocks are overlain in unconformity by molasse-type deposits of early Tertiary age which reach their maximum thickness to the southeast of Tzitzio.

The prevolcanic basement is overlain by 
andesitic to rhyolitic lava flows, domes and pyroclastic products of Oligocene-Early Miocene age belonging to the Sierra Madre Occidental volcanic province (Pasquarè et al., in press). These volcanic products are unconformably overlain by a thick succession of Middle to Late Miocene basalts and andesites which probably represents the basal part of the MVB. These volcanic rocks, which crop out extensively around Lake Cuitzeo and south of Querétaro, also constitute the prePliocene basement to the north (Sierra de S. Inés) and to the south (Sierra de Mil Cumbres) of Los Azufres (Fig. 2).

Latest Miocene-Quaternary silic volcanic activity in the Los Azufres area

Since latest Miocene time widespread silicic volcanism has occurred in the Los Azufres area with the emplacement of various ignimbritic suites and pyroclastic flows and several dome complexes; they will be described in the following paragraphs.

\section{El Terrero ignimbrite}

This ignimbrite, exposed to the north of Los Azufres (Fig. 3), is a light brown mediumwelded ash-flow tuff containing abundant plagioclase phenocrysts and small pumice lumps and scattered lithic fragments. Analyzed samples (our unpublished data) range in composition between quartz-andesites and dacites. A sample collected near the village of El Terrero, north of the Sierra de S. Ines, yield a radiometric age of $6.12 \pm 0.6 \mathrm{Ma}$ (Table 1). Similar ignimbrites, exposed to the north and the east of Tlalpujahua (part of the Fm. Las Américas of Fries, 1965), were tentatively correlated with the El Terrero ignimbrite on stratigraphic and volcanological criteria. In those places the El Terrero Ignimbrite is overlain by a younger ash flow with provenance from the Los Azufres area (Fig. 3, section VIII). In the northernmost outcrops the El Terrero ignimbrite is also cov- ered by a younger ignimbrite which can be followed with continuity up to the Amealco caldera, located about $50 \mathrm{~km}$ northeast of Los Azufres. We obtained a radiometric age of $3.83 \pm 0.4 \mathrm{Ma}$ (Table 1) for a sample of the Amealco ignimbrite collected near the village of Sabanilla, some $25 \mathrm{~km}$ south of Querétaro.

The El Terrero ignimbrite pinches out northeastward against topographical highs made of older rocks (Figs. 2 and 3) indicating a provenance from the south or the west where it is covered by younger rocks. The only possible source in such direction is located in the Los Azufres area since the fault-bounded Lake Cuitzeo basin is a pure tectonic depression (Garduño et al., in press). If the correlations we made are correct, the El Terrero ignimbrite extends from Los Azufres for at least $60 \mathrm{~km}$ (Fig. 3). Known outcrops account for an area of about $170 \mathrm{~km}^{2}$ with an average thickness of $30 \mathrm{~m}$. Relying on these data, the volume estimate of the presently outcropping ignimbrite approximates $5.1 \mathrm{~km}^{3}$. Extrapolating the original extension of the El Terrero ignimbrite to the area inferred in Fig. 3 (about $1,000 \mathrm{~km}^{2}$ ), and maintaining the same thickness, the total volume would have been on the order of $30 \mathrm{~km}^{3}$.

\section{Pucuato ignimbrite}

This unit is widely exposed south of Los Azufres but it is sometimes difficult to recognize because its outcrops are often quite inaccessible and eroded. Its basal part, observed on the northern slope of the Sierra de Mil Cumbres, consists of a breccia 10-20 $\mathrm{m}$ thick, with blocks up to $1 \mathrm{~m}$ in size, comprised of older rocks mostly andesitic in composition. This layer is overlain by $15 \mathrm{~m}$ of a glassy, lithic-rich ash-flow tuff, pink in colour, and is capped by an air-fall deposits consisting mainly of pumice (80\%) and millimetric andesitic lithic fragments. The air-fall products reach a maximum thickness of $40 \mathrm{~m}$ in the Pucuato plateau, some tens of $\mathrm{km}$ south of Cd. Hidalgo. The Pucuato ignimbrite has not 

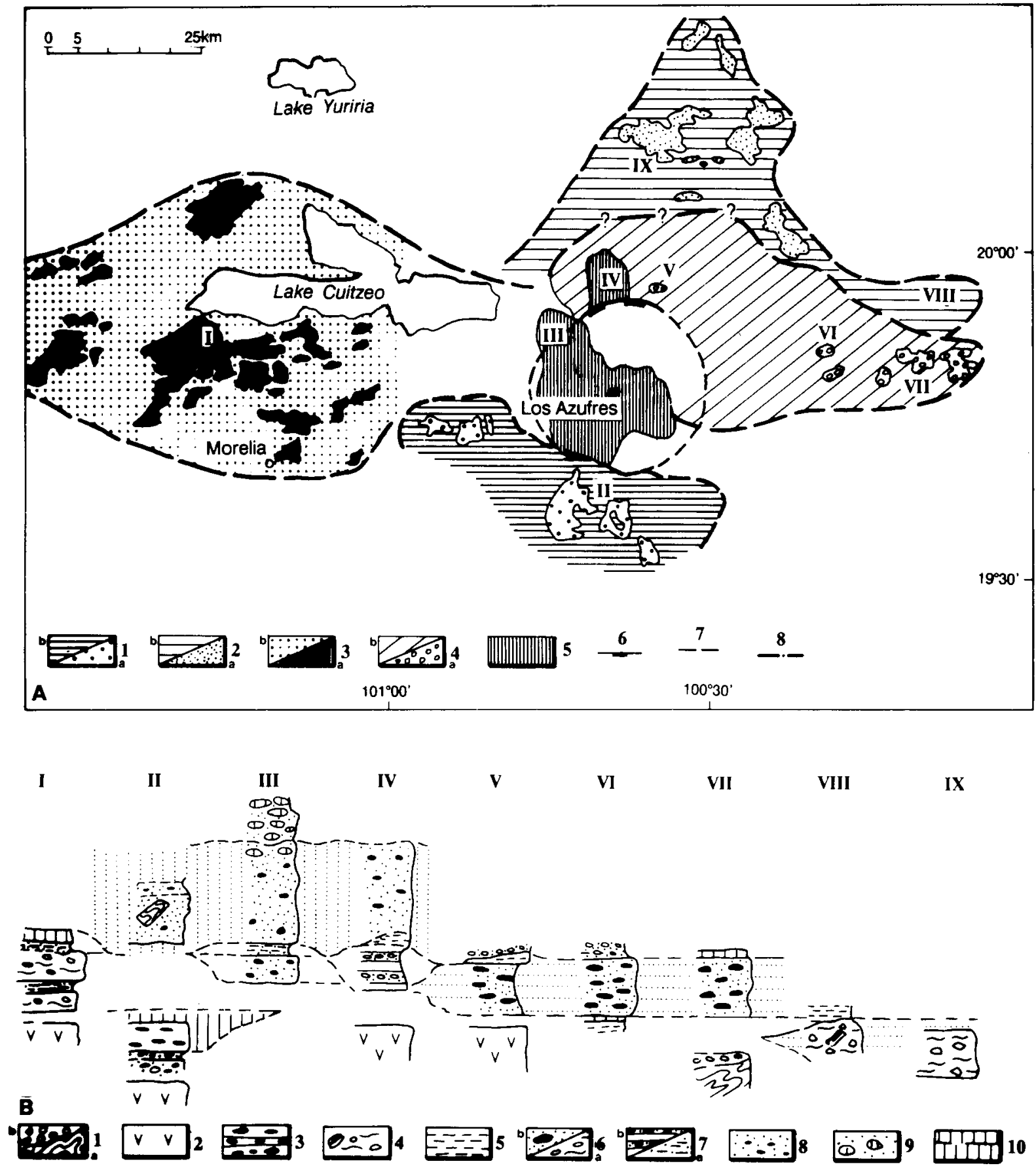

Fig. 3.(A) Sketch-map showing outcrops (a) and possible extension (b) of the pyroclastic units. Roman numerals indicate location of stratigraphic sections in Fig. 3B. $1=$ Pucuato ignimbrite; $2=$ El Terrero ignimbrite; $3=$ Lake Cuitzeo ignimbrite; $4=$ Inés ignimbrite; $5=$ areal distribution of the Pueblo Viejo pyroclastic deposits; $6=$ visible caldera rim; $7=\operatorname{limit}$ of the total collapsed area; $8=$ inferred original limits of the ignimbritic sheets.

(B) Representative stratigraphic sections (locations given in Fig. 3A). $I=$ pre-volcanic basement: Mesozoic metamorphic rocks (a) and Cenozoic red beds (b); $2=$ Miocene andesites; $3=$ Pucuato ignimbrite; $4=$ El Terrero ignimbrite; $5=$ Late Miocene-Pliocene lacustrine deposits; $6=$ Lake Cuitzeo (a) and S. Inés (b) ignimbrite; $7=$ lacustrine (a) and fluvial (b) deposits; $8=$ Pueblo Viejo pyroclastic deposits; $9=$ air-fall deposits with large pumice; $10=$ Pleistocene basalts. Dotted and ruled areas represent the correlation of the various units. Not to scale. 
been radiometrically dated but can be related to the latest Miocene or Early Pliocene because it overlies Late Miocene rocks but rests on topographic highs that remained from the Late Pliocene extensional tectonics.

The large size of the blocks, included in the basal breccia, point to a source area relatively close to the present outcrops. On the ther hand, no realistic source for this ignimbrite can be found southward, in the highly dissected Sierra de Mil Cumbres (Fig. 2). We thus suggest as a probable source the La Venta depression, located south of Los Azufres (Fig. 4).

The present outcrops of the Pucuato ignimbrite account for about $100 \mathrm{~km}^{2}$ while the original extension is highly speculative (Fig. 3 ). Taking an average thickness of $50 \mathrm{~m}$, the volume of the exposed rocks is $4.8 \mathrm{~km}^{3}$. The original volume is very difficult to evaluate but could have been three times as much.

\section{Siete Cruces, El Fraile and Apaseo dome complexes}

Various dome complexes, unrelated to caldera structures or volcanic centres, are present in the area surrounding Los Azufres. The southwestern side of the Sierra de Siete Cruces (Fig. 2) mainly consists of rhyolitic flows made of rare phenocrysts of quartz, oligoclase and sanidine in a glassy matrix. The rhyolites were probably part of a complex of exogenous domes that have been highly eroded and partly covered by younger rocks. Sanidine phenocrysts from a sample collected near the village of Puroagua, on the southwestern slope of the Sierra de Siete Cruces, yielded a $\mathrm{K}-\mathrm{Ar}$ age of $5.45 \pm 0.5 \mathrm{Ma}$ (Table 1).

The Sierra El Fraile, south of Los Azufres, consists of a large complex of coalescing endogenous domes; deposits of hot avalanches have been observed locally. The rocks are typically dacites with phenocrysts of hornblende, biotite and sodic plagioclase in a glassy groundmass containing plagioclase microlites. The amount of differentiated magma erupted in the dome complex of Sierra El Fraile is of considerable volume, being in the order of $100 \mathrm{~km}^{3}$ (the maximum height of the complex is about $850 \mathrm{~m}$ and it covers an area of $180 \mathrm{~km}^{2}$ approximately). A radiometric age of $4.3 \pm 0.3 \mathrm{Ma}$ (Table 1) was obtained from a dacitic sample collected at the locality of $\mathrm{El}$ Dorado, $10 \mathrm{~km}$ ESE of Ciudad Hidalgo.

Near the village of Apaseo el Alto, $30 \mathrm{~km}$ WSW of Querétaro (Fig. 2), several large exogenous domes are present. They are made of highly altered devitrified rhyolite with a marked fluidal texture and are almost free of phenocrysts. The Apaseo domes are emplaced above a basaltic plateau dated between 8 and $6 \mathrm{Ma}$ and are overlain by small basaltic shield volcanoes of Pleistocene age; consequently we suppose that the Apaseo domes were emplaced during the Early Pliocene as in the case of the Siete Cruces and El Fraile complexes.

\section{Lake Cuitzeo ignimbrite}

The main exposures of this unit are around Lake Cuitzeo, where it covers a Late Miocene succession of andesites and basalts, and near the city of Morelia (Fig. 2), where it has been exploited as a building stone. This ignimbritic suite presents different facies, varying from a gray or violet, glassy welded ash-flow tuff to an almost unconsolidated white ash flow. South of Lake Cuitzeo, the ignimbrite consists of two main eruptive units separated by about $10 \mathrm{~m}$ of lacustrine sediments. The lower unit is characterized by various poorly welded ash flows with thin layers of air-fall ash. The upper unit consists of pink to violet ash-flow tuffs with phenocrysts of quartz, sanidine, plagioclase and few orthopyroxenes with rare lithic and pumice fragments up to $1 \mathrm{~cm}$ in size. The sequence is capped by alternating layers of ash, pumice and lacustrine siltstones. Northwest of Lake Cuitzeo, only the upper ignimbrite unit is found. It is welded with rare phenocrysts of quartz, sanidine and andesine plagioclase and collapsed pumice ranging up 
to $10 \mathrm{~cm}$ in length. Sanidine crystals from a glassy ash-flow tuff north of Lake Cuitzeo yielded a radiometric age of $2.8 \pm 0.2 \mathrm{Ma}$ (Table 1). To the west of Lake Cuitzeo the ignimbrite is covered by Late Pleistocene basaltic flows, making precise determination of the actual extension impossible. We estimate the original extension to have been nearly 2,000 $\mathrm{km}^{2}$ (Fig. 3), with an average thickness of almost $40 \mathrm{~m}$. Therefore, the probable original volume is on the order of $80 \mathrm{~km}^{3}$.

\section{S. Inés ignimbrite}

The unit is exposed in scattered outcrops in the Sierra de S. Inés and northwest of Tlalpujahua (Fig. 2). In the former site the ignimbrite rests unconformably on Late Miocene andesites which are tilted up to $10^{\circ}$ toward the north, while in the latter area it overlies an older ash-flow deposit tentatively correlated with the El Terrero ignimbrite. The ignimbrite consists of two eruptive units. The lower one is a light gray or light brown tuff up to 25 $\mathrm{m}$ thick with black fiamme up to $50 \mathrm{~cm}$ long which contain perlite. Lithic fragments consists of angular blocks (up to $20 \mathrm{~cm}$ in size) of older andesites and dacites and are diffusely distributed in the tuff. This body is capped by $3 \mathrm{~m}$ of a brown welded tuff with small white pumice. A few meters of an air-fall deposit are sometimes observed on top of the ignimbrite. A correlative ignimbritic sequence is found in the Tlalpujahua area, resting on a lacustrine deposit with diatomaceous sediments of Late Miocene age (Garduño, 1988). In this area the ignimbrite is $10 \mathrm{~m}$ thick. The estimate of the actual exposures approach 45 $\mathrm{km}^{2}$ while its volume amounts to $1.3 \mathrm{~km}^{3}$.

\section{Zinapécuaro domes}

This unit consists of several isolated domes emplaced around the village of Zinapécuaro, between Los Azufres and Lake Cuitzeo (Fig. 4). Hot avalanche deposits, produced by the breaching of the carapace, are sometimes observed. The lavas are light gray, flow-banded rhyolites, rich of obsidian and with well developed spherulites. The domes vary in composition from rhyolites to high-silica rhyolites, with quartz, K-feldspar and plagioclase as main components. The Zinapécuaro domes yielded $\mathrm{K}-\mathrm{Ar}$ ages ranging between 1.6 and 1.14 Ma (see Tables 1 and 2).

\section{Los Azufres volcano and summit domes}

Andesitic aphanitic lavas outcrop to the north and to the south of Los Azufres (Fig. 4). These rocks were previously interpreted as resurgent "basement" rocks, chronologically equivalent with the Sierra de S. Inés ones (Pradal and Robin, 1985). Nevertheless, the dating of these lavas to the Pleistocene (Table 2; Comisión Federal de Electricidad (C.F.E.) unpublished data) and the fact that they gently dip in opposite directions, support a different interpretation (Pasquarè, 1986). In our view, these andesites represent the northern and southern slopes of a lava cone of Pleistocene age covered for the remaining part by younger domes. K-Ar dates of samples collected in the geothermal drillings at Los Azufres (Table 2) suggest a thickness of about $700-800 \mathrm{~m}$ for the andesites belonging to the volcano which, at least in its southern part, seems to lie upon an ignimbrite unit dated 3.1 Ma (Garduño, 1988). The summit area of the Los Azufres volcanic centre, where the geothermal field is located, is occupied by two large exogenous domes emplaced between 1.03 and $0.84 \mathrm{Ma}$ (Table 2), whose total volume was estimated to be $10-15 \mathrm{~km}^{3}$ (Dobson and Mahood, 1985). Lavas are rhyodacites and rhyolites with fluidal texture and contain phenocrysts of plagioclase, sanidine, quartz and biotite. Rocks are locally very altered due to the persistant hydrothermal activity related to the geothermal system.

\section{Dacitic domes}

The Cerro S. Andrés, located just to the east of Los Azufres, is a large vent complex which produced two thick flows and rep- 


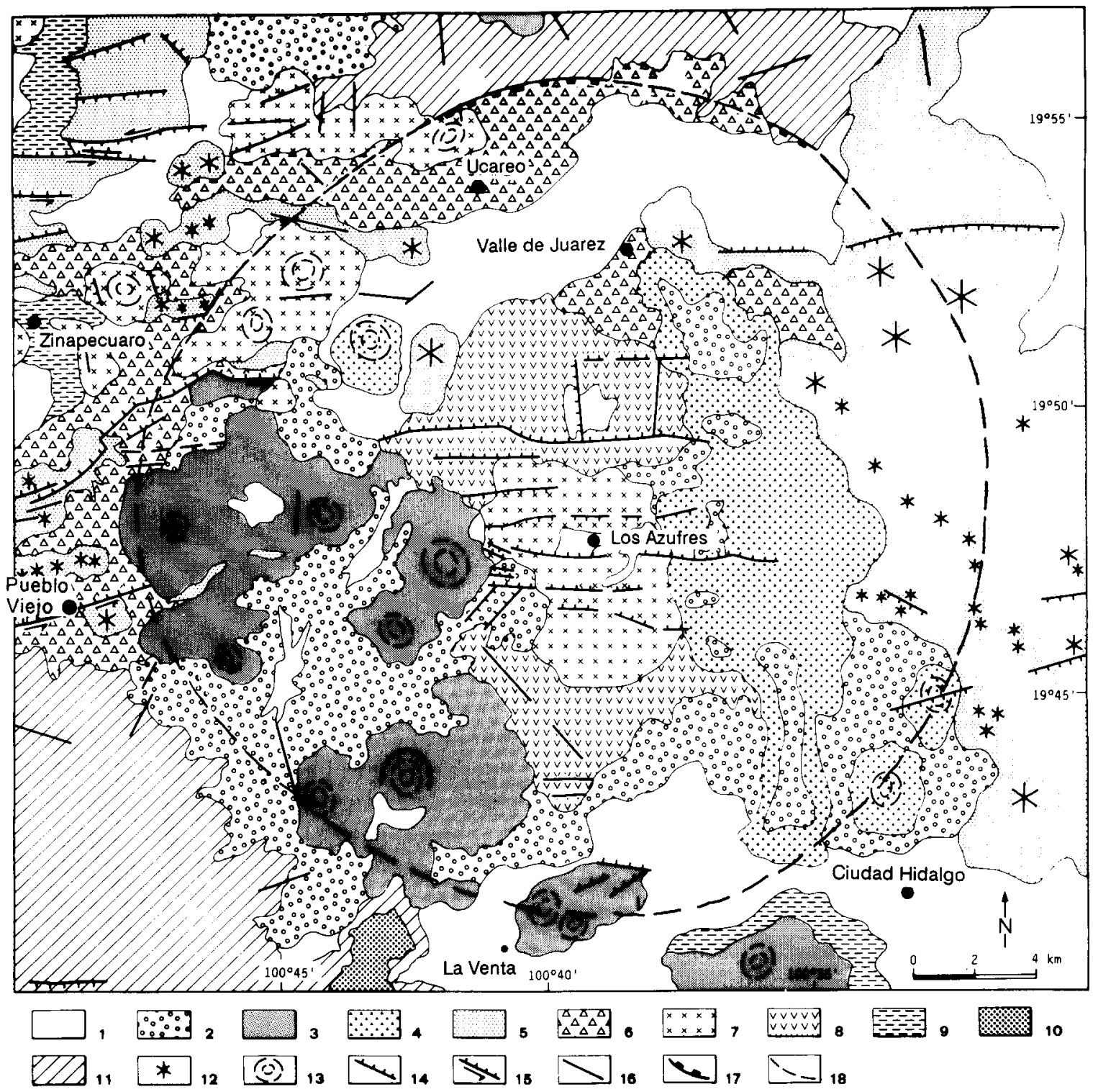

Fig. 4. Geology of the Los Azufres area. $I=$ alluvial deposits; $2=$ pyroclastic deposits related to the late Pleistocene domes; $3=$ Late Pleistocene rhyolitic domes; 4 = Cerro S. Andrés and related dacitic domes; 5 = Pleistocene basaltic cinder cones and flows; 6 = fluviolacustrine deposits partially made of pyroclastics related to the Zinapécuaro domes; $7=$ Early Pleistocene rhyolitic domes; $8=$ Los Azufres volcano; $9=$ lacustrine sediments; $10=$ Pucuato ignimbrite; $11=$ Late Miocene andesites; $12=$ cinder cones; $13=$ domes; $14=$ normal faults; $15=$ oblique slip faults; $16=$ fracture or faults with undetected motions; $17=$ visible caldera rim; $18=$ inferred total collapsed area.

resents the major peak of the Los Azufres area. It covers an area of about $70 \mathrm{~km}^{2}$ and the volume is estimated in $15-20 \mathrm{~km}^{3}$. Lavas are dacites and rhyodacites with phenocrysts of plagioclase and hornblende; inclu- sions of aphyric andesites are often present. An age of $0.33 \pm 0.07 \mathrm{Ma}$ was obtained for the S. Andrés dacites (Table 2). Southeast of Cerro S. Andrés there are small satellite domes of similar composition. Cerro Mozo, 
another dacitic dome located $12 \mathrm{~km}$ WNW of Cerro S. Andrés, is composed of a glassy lava with small phenocrysts of andesine, quartz and oligoclase. Radiometric dating (C.F.E., unpublished data) of this dome, yielded ages comparable with the one obtained for the Cerro S. Andrés. The Cerro Mozo is surrounded by a thick blanket of pyroclastic deposits probably related to its evolution.

\section{Pueblo Viejo pyroclastic flows}

Under this heading we group several pyroclastic flow deposits cropping out in the southern part of the Los Azufres depression and which display their maximum thickness near the village of Pueblo Viejo (Fig. 4). In this area the succession consists of three pumice flows. The basal unit is characterized by the presence of black pumice and andesitic fragments and is overlain by a $80-\mathrm{cm}$-thick paleosoil. A second pumice flow is distinguishable because of a glassy matrix and the presence of charcoal fragments. The sequence is capped by a third flow with rhyolitic pumices up to $25 \mathrm{~cm}$ long. South of Los Azufres similar flows are underlain by surge deposits. These deposits are presumably Middle Pleistocene in age because they rest on a basaltic andesite flow dated at $0.87 \pm 0.17 \mathrm{Ma}$ (Table 1). Another very recent pyroclastic deposit is found around the town of Acámbaro, located northwest of the Sierra de S. Inés. It consists of an air-fall deposit overlain by a basal surge and an ash flow containing pumices, obsidian and andesite fragments. The lower part of the sequence is deposited in a paleolacustrine depression.

\section{Recent domes}

Many rhyodacitic to rhyolitic domes are emplaced in wide areas southwest of Los Azufres and represent the youngest eruptive event in the area. The lavas are very glassy with few phenocrysts of plagioclase and sanidine. Three domes yielded $\mathrm{K}-\mathrm{Ar}$ ages ranging between 0.30 and $0.14 \mathrm{Ma}$ (Table 2); a more recent age of 28.000 years (Garduño, 1988) was reported for a pyroclastic deposit related to the Guangoche dome, located in the most southwestern part of the area. This dome consists of a large crater almost completely filled by another small dome. The crater was probably the result of an explosive event which produced a blanket of pumice and ash deposits up to $25 \mathrm{~m}$ thick in this area. Late Pleistocene silicic volcanism is also widespread outside the Los Azufres area where an age of $0.05 \mathrm{Ma}$ (Table 2) was reported for a rhyodacitic dome north of Zitácuaro (Fig. 2). East of this town, a large complex of rhyolitic domes of very recent age with associated thick pyroclastic deposits is also present.

\section{Fluviolacustrine deposits}

Two main depressions represent the morphological evidence of the Los Azufres caldera system: a northern depression (Valle de Juárez), limited to the north by the Sierra de S. Inés massif and a southern one ( $\mathrm{La}$ Venta depression), bounded to the south by the Sierra de Mil Cumbres massif. These depressions were filled by epiclastic fluviolacustrine deposits made of moderately consolidated, thin layers of siltstones and ashes with horizons containing pumice, obsidian and andesite fragments. In the Valle de Juárez depression, near the village of S. Ildefonso, these sediments unconformably overlie the Late Miocene andesites of the Sierra de S. Inés and just to the east they are covered by the Middle Pleistocene basaltic flows of Cerro La Calabaza. In the La Venta depression, near the village of Huajúmbaro, the sedimentary deposits consist of two sequences of conglomerates, tuffaceous sandstones, siltstones and diatomites overlain by recent pyroclastic deposits. The lower succession is tilted $25^{\circ}$ to the south, suggesting the existence of two main tectonic events. 


\section{Pleistocene basalts}

Various basaltic flows crop out in the outskirts of the Los Azufres depressions. They have mostly a microcrystalline texture with plagioclase, clinopyroxene and magnetite microlites. Southwest of the village of Ucareo, in the Valle de Juárez depression (Fig. 4), one of these basaltic flows covers Early Pleistocene rhyolitic flows coming from the Mesa Grande dome (Zinapécuaro domes). A sample collected in place gave a radiometric age of $0.75 \pm 0.15 \mathrm{Ma}$. Another basaltic sample collected about $5 \mathrm{~km}$ to the south, near the Morelia-Maravatio road, yielded a comparable age of $0.87 \pm 0.17 \mathrm{Ma}$ (Table 1). Basaltic volcanism of Middle Pleistocene age is widespread in the region west of Los Azufres (Hasenaka and Carmichael, 1985) and also along the southeastern shore of Lake Cuitzeo where several cinder cones, with a marked E-W alignment (Pasquarè et al., in press), overlie pyroclastic deposits related to the Zinapécuaro domes. To the east of Los Azufres, many basaltic cinder cones, which appear morphologically younger, are aligned along E-W and NW-SE trends.

\section{Regional tectonics}

\section{Structural architecture}

The regional structural architecture is dominated by an impressive extensional fault system which forms a continuous succession of grabens and semigrabens (Fig. 5). Depressions are limited by en-echelon dog-leg faults striking from $\mathrm{E}-\mathrm{W}$ to NE-SW (Tibaldi, 1989). Volcanic and sedimentary successions are tilted mainly south-southeastward, according to the NNW principal fault dip. Pervasive secondary faulting parallel and perpendicular to the graben elongation also disrupt the tilted blocks. En-echelon structures show an E-W line of bearing which gives rise to the general $\mathrm{E}-\mathrm{W}$ elongation of the exten- sional pattern of the area. These structures link the Tzitzio high, in the southern part of the area, to the Celaya-Querétaro depression in the north (Fig. 5). The Tzitzio high is a moderately asymmetrical open anticline with a NNW-SSE 100-km-long axis, involving the metamorphic basement and the PalaeogeneEarly Miocene volcano-sedimentary units. Multiphase folds with different orientations are widespread in the Tlalpujahua area, eastsoutheast of Los Azufres. Compressional structures are also expressed by thrust, reverse and strike-slip faults with a variety of orientations. This complex distribution of brittle features is due to the juxtaposition of several tectonic phases.

\section{Tectonic phases}

\section{Pre-Pliocene tectonics}

Metamorphic basement was involved at least in two folding phases of post-Jurassic age following noncoaxial directions of shortening. Radiometric age determinations and stratigraphic relationships constrain the development of the Tzitzio anticline to the end of Early Miocene (Ferrari et al., 1990).

Following this compressional event, N-Strending Basin-and-Range extensional structures developed in the northern part of the area (Pasquarè et al., 1988). Most of these structures were buried by the subsequent volcanic activity, and precise temporal location of this phase requires further investigation.

\section{Late Miocene-Early Pliocene tectonics}

Up to the beginning of the Late Miocene, rock units are displaced by rare $\mathrm{N} 25^{\circ}-45^{\circ}$ right-lateral and by several $\mathrm{N} 60^{\circ}-75^{\circ}$ leftlateral en-echelon strike-slip faults. These sets of faults can be conjugated in a system with an acute angle ranging between $30^{\circ}$ and $90^{\circ}$ (Fig. 6A). Motions are characterized by pitches of less than $45^{\circ}$ while the dip of the fault planes ranges between $65^{\circ}$ and $90^{\circ}$. The same rock units are also disrupted by rare $\mathrm{N}$ 


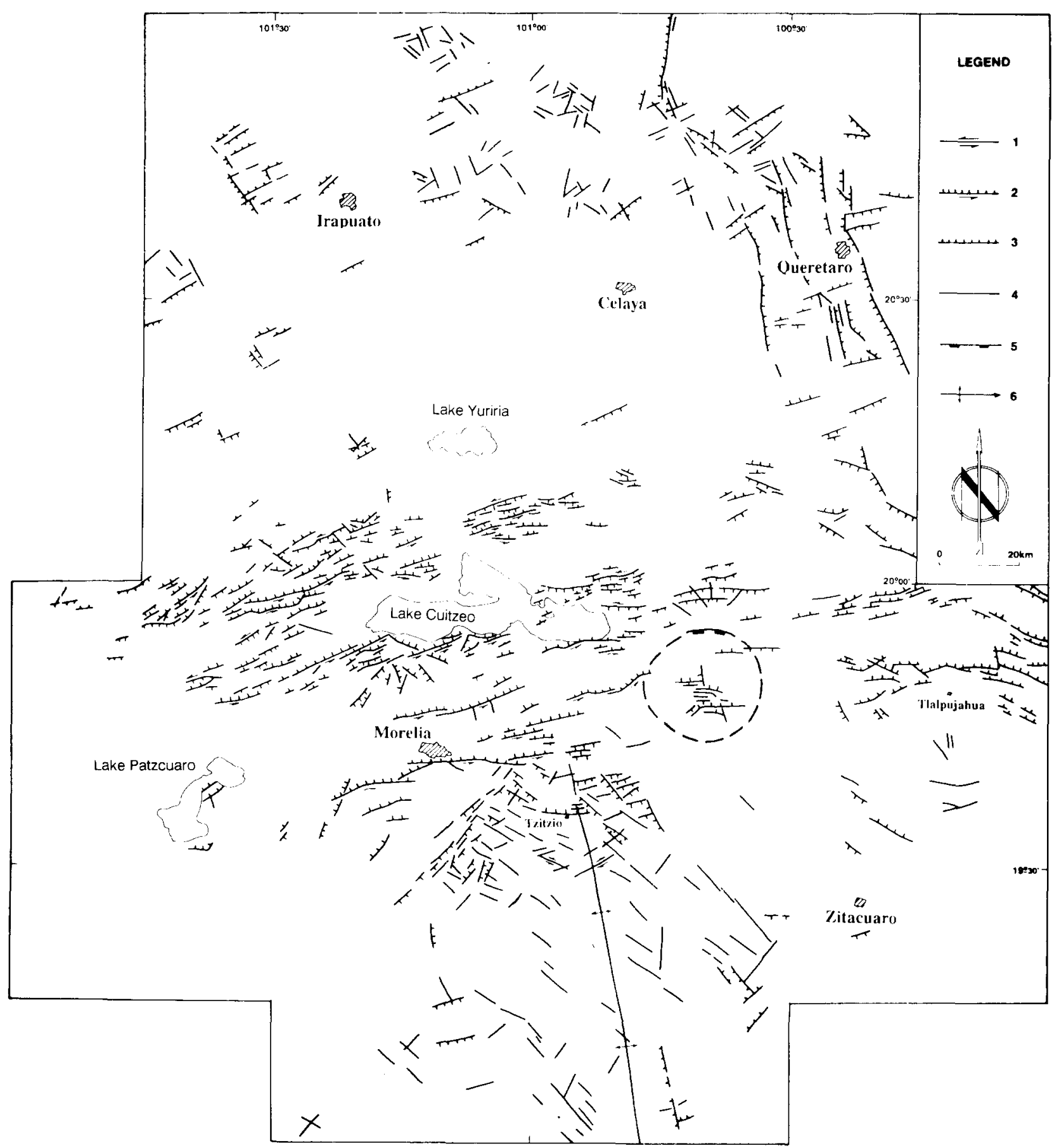

Fig. 5. Regional structural map and limit of the total collapsed area of the Los Azufres nested caldera (dashed line). $l=$ strike-slip fault; $2=$ left-lateral normal fault; 3 = pure normal fault; $4=$ master joint or fault with undetected motion vector; $5=$ outcropping Los Azufres caldera rim; $6=$ Tzitzio anticline. 
$145^{\circ}-160^{\circ}$ en-echelon reverse faults with dips between $35^{\circ}$ and $70^{\circ}$ and pitches between $75^{\circ}$ and $90^{\circ}$. Net slips are of the order of tens of $\mathrm{cm}$.

From a regional point of view this style of deformation is confined to the MVB. All data fit the interpretation of Pliocene wrench tectonics characterized by $\mathrm{N} 60^{\circ}-75^{\circ}$ synthetic Riedel shear (R1), N $25^{\circ}-45^{\circ}$ antitethic Riedel shear (R2) and $\mathrm{N} 145^{\circ}-160^{\circ}$ reverse faults bisecting the obtuse angle of the other two sets.

Using nonrotated slickenside fault planes, stress tensors were computed with a program based on Carey's algorithm (Carey, 1979). Stress tensor data were published in Pasquarè et al. (1988), Tibaldi (1989) and Ferrari et al. (1990). The strike-slip faults of this phase and the reverse faults are consistent with the computed average greatest principal stress $\left(\sigma_{1}\right)$ which is horizontal and oriented $\mathrm{N} 49^{\circ}$. The least principal stress $\left(\sigma_{3}\right)$ is horizontal and shows an average $\mathrm{N} 139^{\circ}$ orientation.

\section{Latest Pliocene-Middle Pleistocene tectonics}

Up to the beginning of the Late Pleistocene, volcanic and sedimentary units are disrupted by a pervasive system of $\mathrm{N} 60^{\circ}-$ $75^{\circ}$ en-echelon faults (Fig. 6B) dipping mainly towards the north-northwest. In some places these faults define narrow grabens. The Sshaped outline of these grabens is due to changes in the direction of the faults (Tibaldi, 1989). The longest fault follows the southern shore of Lake Cuitzeo, with a length of $16 \mathrm{~km}$ while the maximum dip-slips are in the order of hundreds of meters. The faults limit blocks that are mostly tilted $5^{\circ}$ to $20^{\circ}$ toward the south-southeast. These blocks are also closely fractured and displaced by secondary systems. This extensional pattern creates a topographical stairway, from the Tzitzio structural high to the Celaya-Querétaro depression. Cuitzeo Lake is located on an intermediate step of this system limited by WSW-ENE and E-W extensional faults. The $\mathrm{N} 80^{\circ}-10^{\circ}$ faults constitute an important structural feature: although less developed they are continuous for long distances. The longest fault of this system is the Morelia fault, which reaches a length of $15 \mathrm{~km}$. The $\mathrm{N} 60^{\circ}-100^{\circ}$ faults are characterized by left-lateral normal movements. The slickensides have pitches higher than $50^{\circ}$. The fault planes generally dip between $46^{\circ}$ and $80^{\circ}$.

Fault scarp morphology and displaced rock units suggest that the NNW-SSE normal faults of the area around Querétaro (Fig. 5)
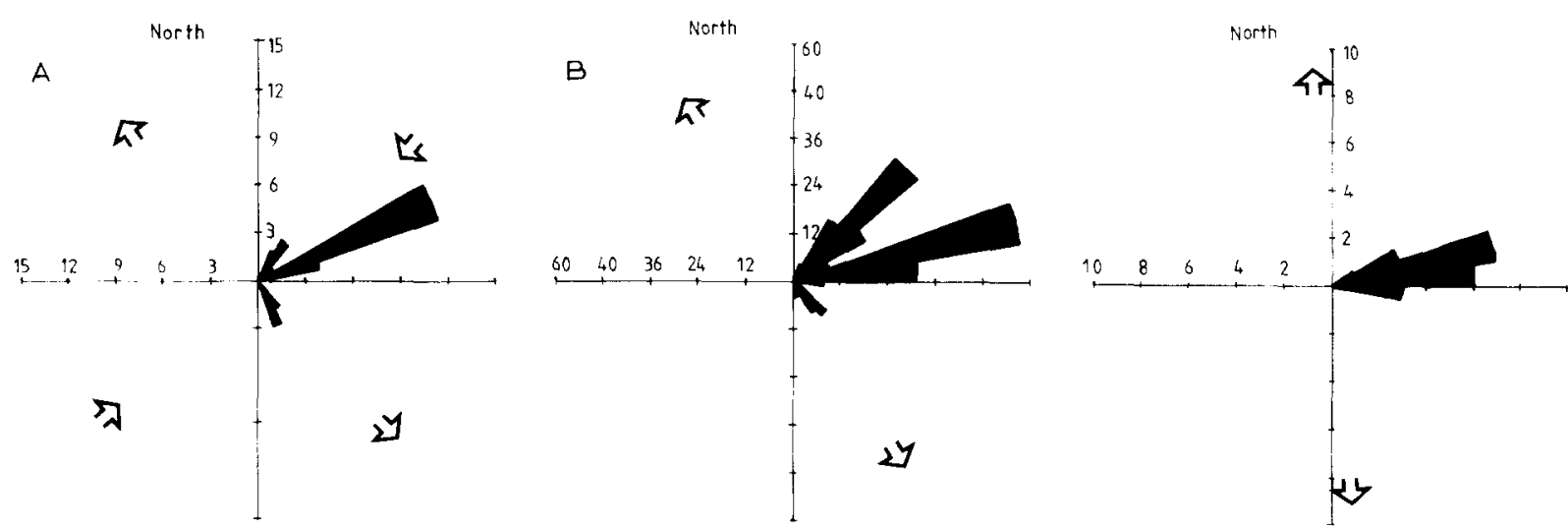

Fig. 6. Rose diagrams of azimuthal distribution of fault strike active in the area of Fig. 5 during: A. Late Miocene-Early Pliocene, B. Latest Pliocene-Middle Pleistocene, C. Late Pleistocene-Holocene. Converging and diverging arrows represent the average directions of the greatest $\left(\sigma_{l}\right)$ and least principal stress $\left(\sigma_{3}\right)$ respectively, computed from the inversion of striated fault populations. 
were active at least during the Early Pleistocene. This grid-like fault distribution caused a block structure with tilting in various directions. We believe that the motions along the NNW-SSE system represent the reactivation of older fault planes which are widely developed to the north of the area of study. On the whole, the data agree with the development, in the Latest Pliocene-Middle Pleistocene, of left-lateral transtensional tectonics following an $\mathrm{E}-\mathrm{W}$ divergent wrenching zone (in the sense of Wilcox et al.. 1973).

The computed stress directions agree with an average value of $\mathrm{N} 149^{\circ}$ for a $\sigma_{3}$ lying on an horizontal plane and fluctuating between $\mathrm{N} 136^{\circ}$ and $\mathrm{N} 165^{\circ}$. Generally, the direction of $\sigma_{3}$ is oblique to the fault planes.

\section{Late Pleistocene-Holocene tectonics}

The limited number of good exposures allowed us to study only a few structural sites in rock units of Late Pleistocene-Holocene age. The collected data are consistent with the presence of normal and left-lateral normal E-W-trending faults (Fig. 6C). Dips range between $55^{\circ}$ and $80^{\circ}$ and pitches are greater than $78^{\circ}$. This suggests that a slightly oblique extensional tectonics is taking place (Fig. 8), in accordance with the left-lateral normal motion along the $\mathrm{E}-\mathrm{W}$ fault plane of the Acambay earthquake of 1912 (Astiz, 1986). Stress tensor solution gives an horizontal $\sigma_{2}$ and $\sigma_{3}$. Strike of $\sigma_{3}$ ranges between NNW-SSE and N-S (Fig. 8).

The last three tectonic pulses, dating from Late Miocene to the present, were grouped in a unique deformation cycle characteristic of an E-W left-lateral shear zone (Pasquarè et al., 1986, 1988; Ferrari et al., 1990). The Late Miocene-Pliocene strike-slip faulting was generated by the first pulses of the incipient shear zone related to parallel wrenching, while the Quaternary deformations represent the surficial expression of the development of the shear zone with movements of divergent wrench type. Quaternary left-lateral transten- sion agrees very well also with seismic (Astiz, 1986) and paleomagnetic data (UrrutiaFucugauchi and Bönhel, 1988).

\section{Tectonics of Los Azufres area}

\section{Caldera rim, fault pattern and stress field}

A possible caldera rim is only present to the north of Los Azufres, where it is marked by a curvilinear eroded fault scarp and other parallel secondary fault scarps (Fig. $4)$. The collapsed area can be only encircled inside a circular feature corresponding to the abrupt disappearance of andesite rocks of the Miocene basement. On the northern side of this circular feature, the Late Miocene andesitic rocks of the Sierra Santa Inés (Figs. 2 and 4) abruptly terminate against the curved fault scarps and are encountered only at depth in the geothermal wells of Los Azufres (Gutiérrez and Aumento, 1982). On the southern side, the Middle Miocene rocks of the Sierra de Mil Cumbres disappear along a circular eroded scarp with a northward convexity. Radial fractures are widespread for the majority in the Sierra de Santa Inés, resembling the typical radial structures of the early stage of development of a caldera (Smith and Bailey, 1968; Garduño, 1988). Caldera rim and radial structures disappear at the contact with the dome complex cropping out NW of Ucareo (Zinapécuaro domes, 1.6 Ma, Table 2) and with Pleistocene basaltic flows east of Valle de Juárez (Fig. 4). These are the only data which permit to infer a geometry to the caldera. Taking into account that inside this depressed area sediment thickness is not constant with our circular feature, we intend to limit the maximum extension of what might be a nested caldera. An higher geometric resolution of the various collapsed sectors is impossible to obtain at the present state of art and probably also in the future because of the extensive recent volcanic cover and tectonics. Therefore, we will simply call this circular ex- 
pression of a nested caldera the Los Azufres caldera.

Several ENE-WSW and E-W normal faults cut volcanic rocks dating up to the Late Pleistocene (Fig. 4). In particular, an E-W fault swarm can be recognized from Los Azufres area to the south of Zinapécuaro and from Valle de Juárez eastwards. These faults, which appear to be younger than the caldera, are part of a regional system, as can be seen by comparing the $\mathrm{N} 50^{\circ}-90^{\circ}$ orientation of these faults (Fig. 8) with the dominant azimuth of the regional Quaternary ones (Figs. 6 and 7). The main fault of the Los Azufres area is an E-W, 1-km-long normal fault and dipping northward. It lies $3.5 \mathrm{~km}$ north of the Los Azufres geothermal field and belongs to the main parallel fault swarm affecting the inner side of the caldera (Fig. 8). In this swarm there are 6 main $\mathrm{E}-\mathrm{W}$ north-dipping normal faults and two antithetic south-dipping normal faults. The two antithetic faults bound the central graben of Los Azufres. Three symmetric grabens of second order are present more to the west-southwest. Two other main faults strike $\mathrm{N}-\mathrm{S}$, disrupting a tilted block limited to the south by the principal $11-\mathrm{km}$-long fault. This fault swarm is not directly linked with the normal faults outside the caldera but lies exactly on their continuation (Fig. 4). An E-W normal fault located $10 \mathrm{~km}$ NNE of the Los Azufres geothermal field dips northward inside the caldera, but at its eastward apparent continuation the dip changes southward (Figs. 4 and 8). The type of motion of the Los Azufres faults (normal with a slight left-lateral component), and their dominant northward dip are in agreement with the characteristics of the regional system.

If these $\mathrm{N} 50^{\circ}-90^{\circ}$-trending faults are independent from any caldera collapse, it is expected that the orientation of the Quaternary stress field inside the caldera equals the regional one. Measurements of 35 striae on Quaternary fault planes were collected within the caldera (Fig. 8). As seen from the stere-
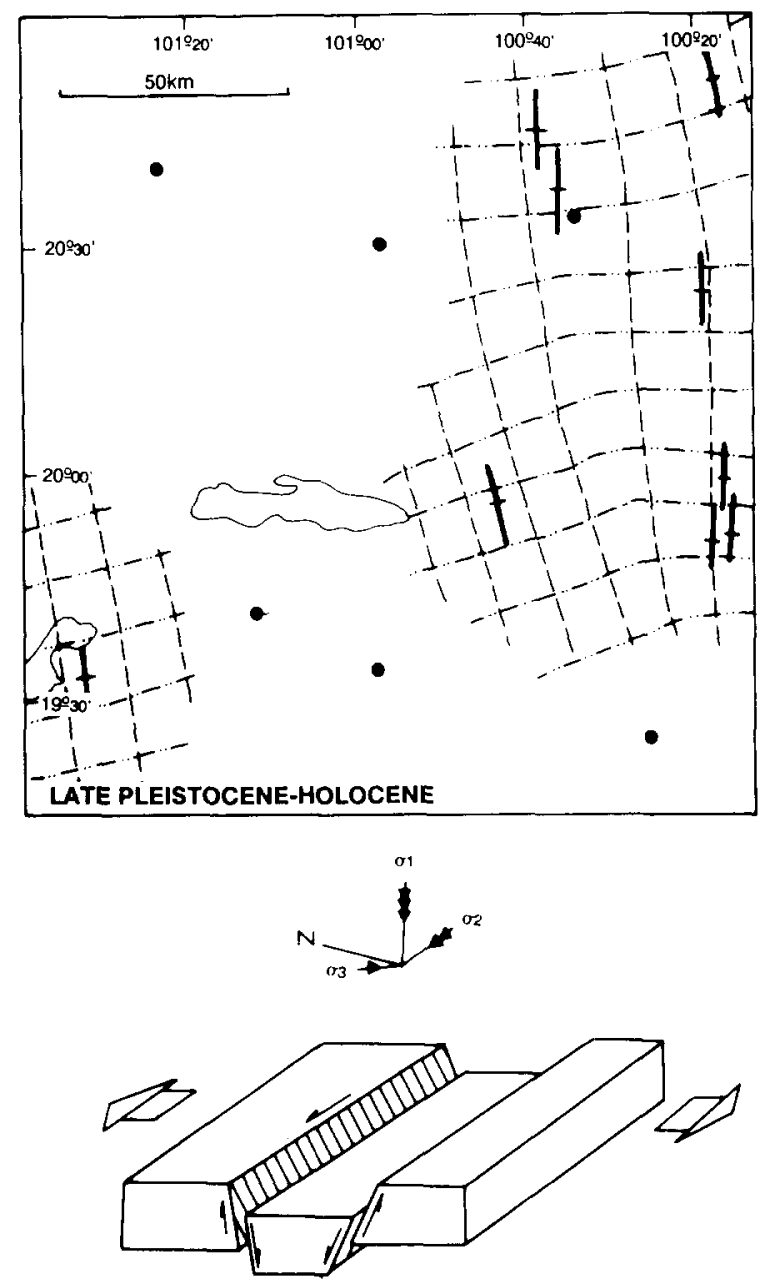

Fig. 7. Regional stress field for the late Pleistocene-Holocene period. Dashed lines and dotted lines represent mean orientation of $\sigma_{\mathrm{Hnin}}$ and $\sigma_{\mathrm{Hmax}}$ respectively; heavy black segment shows local orientation of $\sigma_{\mathbf{H} \text { min }}$ as deduced from inversion of microtectonic data; black dots are localities shown in Fig. 5. Block diagram represents the deformation mechanism for the same period (after Ferrari et al., 1990).

oplot, motion surfaces strike from E-W to ENE-WSW with pitches ranging between $70^{\circ}$ and $90^{\circ}$. These data were processed with a computer program following Carey's method (Carey, 1979) in order to obtain the stress orientation. Computation of stress orientations consistently produced horizontal $\sigma_{3}$ values oriented from $\mathrm{N} 165^{\circ}$ to $\mathrm{N} 180^{\circ}$, in agreement with the Late Pleistocene-Holocene regional stress field (Figs. 6C and 7). 


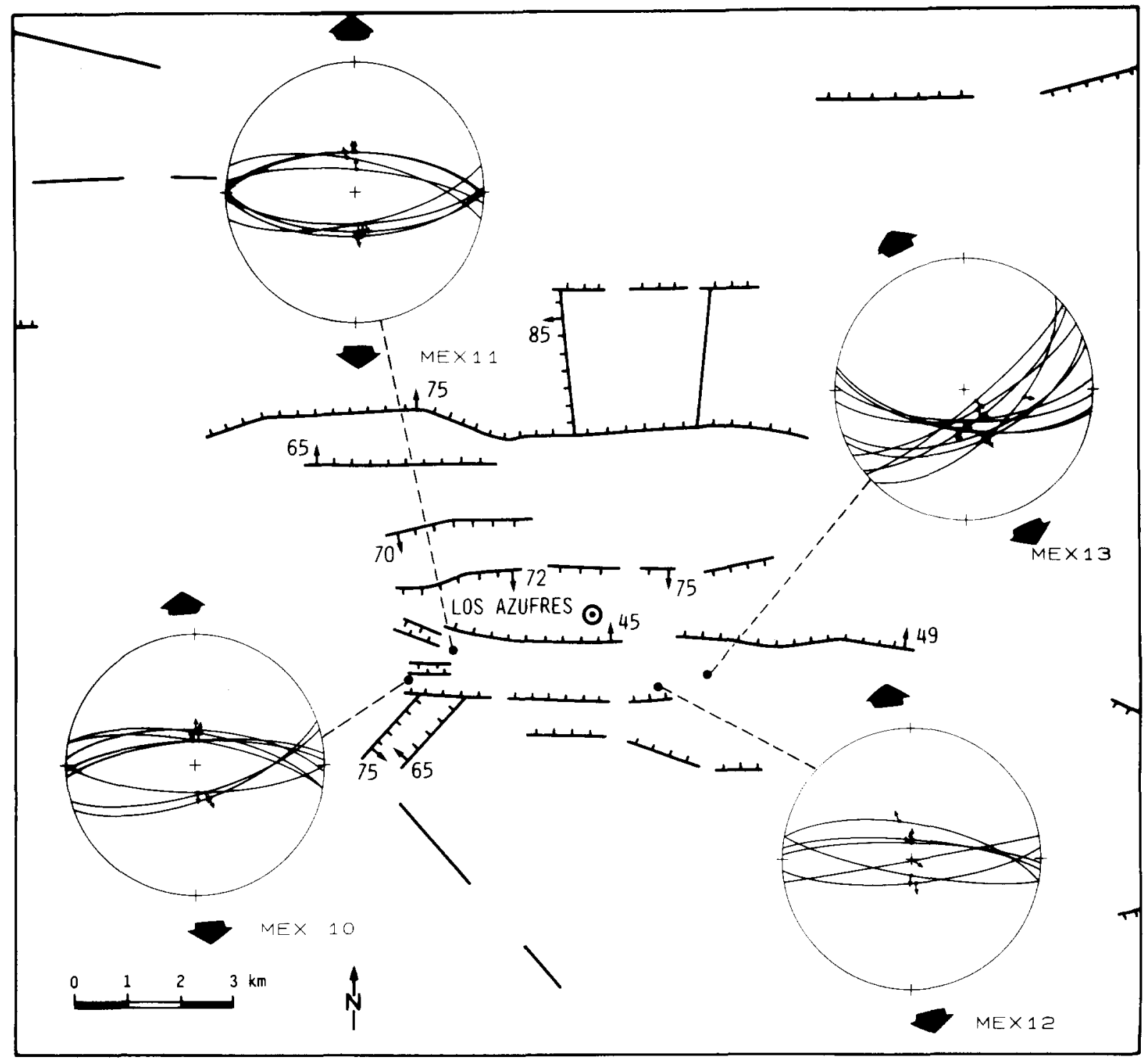

Fig. 8. Structural map of main faults inside the caldera. Numbers denote fault plane rake. Main and secondary fault planes and motion vectors detected at four structural sites are plotted as lower hemisphere projection on Schmidt stereograms. Divergent large arrows show computed directions of the least principal stress $\left(\sigma_{3}\right)$.

Several perturbations in regional structural trends may be explained by the presence of a caldera. A few E-W faults change their dip or present some degree of strike variation when crossing the caldera rim. Structurally aligned volcanic features appear to change in composition when approaching the caldera rim. Monogenetic basaltic cones are widespread both to the east and to the west of the caldera, but they are very scarce inside it, where dacitic to rhyolitic domes are dominant. These complications could be related to the interaction between the regional tectonics and the silicic magma chamber existing below the caldera. The effect of the regional $\sigma_{3}$ could have been reduced by the anomalous 
rheology produced by partially molten rock in the chamber. Regional faults maintain their average strike but develop only at shallow levels in the more brittle rocks lying above the magma chamber.

This postcaldera regional episode of normal faulting is responsible for the obliteration of the caldera rim geometry.

\section{Age of postcaldera faulting}

Regional E-W faulting developed in the central sector of the Mexican Volcanic Belt since the Pliocene. Inside the caldera, rocks dating up to the Middle Pleistocene were affected by the E-W faults, while domes younger then $0.3 \mathrm{Ma}$ are not. Seismological data (Suter et al., 1989) show that only some segments of the regional system east of the caldera are active. In fact, seismic activity was recorded on the Acambay fault segment during 1912 A.D., and on the Maravatio fault segment during 1979. A minor seismic event was also felt by people living in the surroundings of Los Azufres at the beginning of this century but it did not produce detectable field deformations (Suter et al., 1989). According to these data we can suppose that a low level of activity, if any, took place along the Los Azufres E-W fault segment during the Late Pleistocene-Holocene.

\section{Discussion and conclusions}

The Los Azufres area presents an unusual concentration of silicic volcanic activity inside the Mexican Volcanic Belt since the latest Miocene. Its long geological and structural evolution is also peculiar if compared with the other silicic centres of the MVB (Verma et al., 1991, this issue) characterized by a relatively short period of activity.

The recognition of four large ignimbrite sheets surrounding the Los Azufres area suggests a long history of caldera collapses, although the precise location of these struc- tures is difficult to identify because of the successive tectonic and volcanic activity. The Pleistocene silicic centres can be enclosed within a relatively depressed area constituted by the Valle de Juárez and La Venta depressions surrounded by Miocene andesite rocks (Fig. 4). The Valle de Juárez depression is limited to the north by a semicircular fault scarp which may represent a caldera rim. Structures related to the northern caldera rim are presumably buried under rhyolitic domes dating back to the Early Pleistocene. The southern side of the La Venta depression is represented by a roughly semicircular alignment of rhyolitic and dacitic domes of Late Pleistocene age and by the limit of the Middle Miocene andesites of the Sierra de Mil Cumbres. These two semicircular features encircle a depressed area where geothermal exploration drillings encountered an anomalously thick, Late Miocene-Early Pliocene volcanic sequence. Around this depression four large ignimbritic sheets were recognized. The large volumes of these pyroclastic flows rule out their provenance from a dome complex. On the other hand, there does not exist any alternative caldera source for these flows in a radius of $200 \mathrm{~km}$. The only already known Amealco caldera, which lies $100 \mathrm{~km}$ NE of Los Azufres, is the source area for a fifth ignimbritic sheet which is clearly distinguishable from the ones described in this work.

All these observations support the basic conclusion that multiple caldera collapses occurred during pre-Quaternary times inside the circular depressed area of Los Azufres. Recent volcanic and tectonic activity unables us to assess a precise geometry of the various collapsed sectors and their related ignimbrites. We thus suggest that Los Azufres is a nested caldera and we limit ourselves to consider the whole depressed area. The total original volume of the ignimbrites was estimated to be $130 \mathrm{~km}^{3}$; this value is comparable with the volume of the total collapsed area, which can be roughly estimated in $180 \mathrm{~km}^{3}$ 
(taking an area of $450 \mathrm{~km}_{2}$ and a collapse of $400 \mathrm{~m}$ ).

On the contrary, it is not possible to compare the volume of the pyroclastic deposits related to the caldera collapse with the volume of their proposed caldera according to Pradal and Robin (1985). In fact, even considering the maximum thickness $(80 \mathrm{~m})$ and the areal extension reported by Pradal and Robin, the volume obtained for these pyroclastics is about $12 \mathrm{~km}^{3}$. By contrast, they proposed a caldera $20 \times 15 \mathrm{~km}$ in size and a collapse of at least $400 \mathrm{~m}$ which give a volume of about $90 \mathrm{~km}^{3}$. In addition, they proposed that the products of the Los Azufres Volcano, which rise at the southern limit of their caldera, have the same age of the andesites of the Sierra de S. Inés, thus supporting a resurgent caldera model. Nevertheless, this inference can be questioned since andesites outcropping at Los Azufres were dated at $1.03 \pm 0.2$ Ma (Table 2) while Late Miocene rocks were encountered only down a depth of about 700 $\mathrm{m}$. Finally, geothermal wells at Los Azufres reach the depth of $-3544 \mathrm{~m}$ (Venegas et al., 1985), without encountering the prevolcanic basement. These data permit to consider the Los Azufres structure as a latest Miocene and Pliocene nested caldera and to refute the Late Pleistocene resurgent caldera model of Pradal and Robin (1985).

Considering the age distribution of dated volcanic products of the area comprised in Figure 2 (Fig. 9), we can observe that the acid activity, occurring between 6.2 and $2.8 \mathrm{Ma}$ in the Los Azufres region, is partly coincident with a gap (5 to $3 \mathrm{Ma}$ ) in basic and intermediate volcanism. These data appear to be coherent with the beginning of a left-lateral shear zone characterized by a Late MiocenePliocene first pulse with transcurrent faulting and a latest Pliocene-Quaternary transtension. The gap may be explained by storage of magma during the compressive pulse, with consequent differentiation and uprising along transcurrent faults.

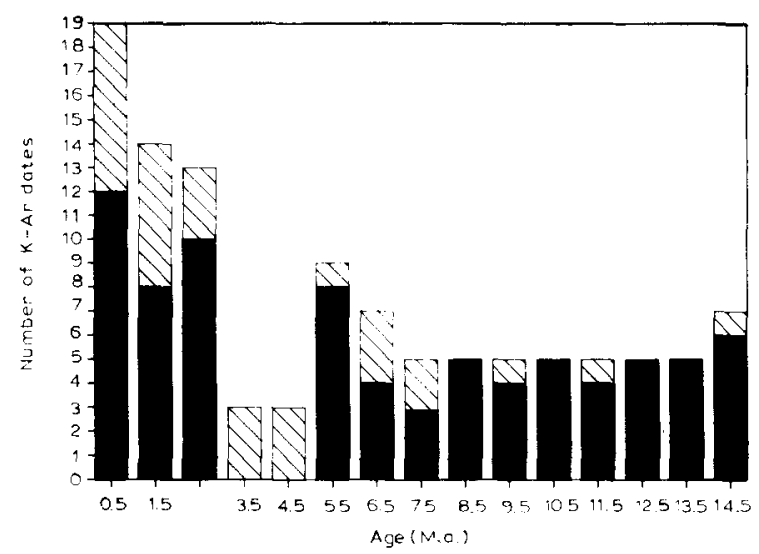

Fig. 9. Histogram of K-Ar age dates of the central part of MVB between longitude $100^{\circ} \mathrm{W}$ and $102^{\circ} \mathrm{W}$. Mafic to intermediate dated rocks are black; silicic dates rocks are shaded. (Data from Aumento and Gutiérrez, 1980; Dobson and Mahood, 1985; Venegas et al., 1985; Nixon et al., 1987; Pasquarè et al. in press; this work, and our other unpublished data.)

The volcanological consequence of the following transtension on the Los Azufres caldera is represented by mixing of new basaltic magmas with the remaining differentiated ones; petrographical evidence for such mixing was reported by Demant (1981) and Chatelineau et al. (1987). Large amounts of basaltic lavas were erupted outside the caldera rim along the main extensional faults. The offset produced by the transtensional phase and the Quaternary volcanic activity in the Los Azufres caldera, contributed to obliterate its original geometry at the point that what is probably the largest caldera structure of the MVB is also the more difficult to be understood.

\section{Acknowledgments}

We are indebted to M. Ferrari and L. Vezzoli, who cooperated in the geological investigations in the area. We are also grateful to F. Innocenti for useful discussions during an early stage of the preparation of the manuscript. The original version of the paper was improved by two anonimous reviewers of JVGR. S.P. Verma also provide useful 
suggestions. This work is part of a research project over a larger area, sponsored by the Ministero Italiano della Pubblica Istruzione, $40 \%$ grant. V.H.G. benefited from a Third World Academy of Science grant; A.T. benefited from an Italian Ph.D. grant. Line drawings were prepared by M. Minoli. The English style was reviewed by A.J. Aghib.

\section{References}

Aumento, F. and Gutiérrez, N.A., 1980. Geocronología de Los Azufres, Michoacán. Intern. Rep. of Comisión Federal de Electricidad, Mexico City, $15 \mathrm{pp}$.

Astiz. L., 1986. The 1912 Acambay, Mexico (Ms $=7.0$ ) earthquake: A reexamination. Bol. Union Geofis. Mex.., II (spec. issue): 17.

Campa, M.F. and Concy, P., 1983. Tectonostratigraphic terranes and mineral resources distribution in Mexico. Can. J. Earth Sci., 20: 1040-1051.

Carey. E.. 1979. Recherche des directions principales de contraintes associées au jeu d'une population des failles. Rev. Géogr. Phys. Geol. Dyn.. 21(1): 57-66.

Chatelineau, M., Oliver, R. and Nieva, D., 1987. Geochemistry of volcanic series of the Los Azufres geothermal field (Mexico). In: S.P. Verma (Editor), Special Volume on Mexican Volcanic Belt-part 3B. Geofís. Int., 26(2): 27.3-290.

Demant, A., 1981. LAxe Néovolcanique Mexicain; étude volcanologique et pétrographique-signification géodynamique. Thèse du doctorat d'Etat, Univ. de AixMarseillc, $259 \mathrm{pp}$.

Dobson, P.F. and Mahood, G.A., 1985. Volcanic stratigraphy of the Los Azufres geothermal area, Mexico. J. Volcanol. Geotherm. Res., 25: 273-287.

Ferrari, L.. Pasquarè. G. and Tibaldi, A., 1990. PlioQuaternary tectonics of central Mexican Volcanic Belt and some constraints on its rifting mode. Geofís. Int., 29: $5-18$.

Fries, C., 1965. Nuevas aportaciones geocronológicas y técnicas empleada en el laboratorio de Geocronometría. Bol. Inst. Geol. Univ. Aut. de Mexico, 73: 57-133.

Garduño, V.H., 1988. La caldera de Los Azufres y su relación con el sistema regional E-W. Geotermia, Rev. Mex. Geoenergia, 4: 49-61.

Garduño, V.H., Israde, I. and Ferrari. M., 1991. Lorigine transtensive du Lac de Cuitzeo. Boll. Soc. Geol. Fr., in press.

Gutiérrez, N.A. and Aumento, F., 1982. The Los Azufres, Michoacán. Mexico, geothermal field. J. Hydrol., 56: $137-$ 162.

Hasenaka, T. and Carmichael, I.S.E., 1985. The cinder cones of Michoacán-Guanajuato, Central Mexico: their age, volume and distribution, and magma discharge rate. J. Volcanol. Geotherm. Res., 25: 105-124.

Israde, I. and Martínez, L., 1986. Contribución al estudio geologico de la transición Pacifico-Tethis en el area de Zitacuaro, Mich. B. Sc. Thesis, Instituto Politecnico Nacional, Mexico, D.F., $128 \mathrm{pp}$.

Mahood, G.A., 1980. Geological evolution of a Pleistocene rhyolitic center: Sierra La Primavera, Mexico. J. Volcanol. Geotherm. Res., 8: 199-230.

Nixon, G.T., Demant, A., Amstrong, R.L. and Harakal, J.E., 1987. K-Ar and geologic data bearing on the age and evolution of the Trans-Mexican Volcanic Belt. In: S.P. Verma (Editor), Special Volume on Mexican Volcanic Belt-Part 3A. Geofís. Int., 26-1: 109-158.

Pasquarè, G., 1986. Interpretación geologica del campo geotermico de Los Azufres. Tech. Rep. ElectroconsultC.F.E., 24 pp.

Pasquarè, G., Forcella, F., Tibaldi, A., Vezzoli, L. and Zanchi, A., 1986. Structural behaviour of a continental volcanic arc: the Mexican Volcanic Belt. In: F.-C. Wezel (Editor), The Origin of Arcs. Elsevier, Amsterdam, pp. 509-527.

Pasquarè, G., Garduño, V.H., Tibaldi, A. and Ferrari, M., 1988. Stress pattern evolution in the Central Sector of the Mexican Volcanic Belt. Tectonophysics. 146: 352-364.

Pasquarè, G., Ferrari, L., Garduño, V.H., Tibaldi, A. and Vezzoli, L., in press. Geology of the central sector of Mexican Volcanic Belt, States of Guanajuato and Michoacán. Geol. Soc. Am. Map and Chart Series.

Pasquarè, G., Tibaldi, A., Attolini, M. and Cecconi, G., 1988. Morphometry, spatial distribution and tectonic control of Quaternary volcanoes in Northern Michoacan. Mexico. Rend. Soc. Ital. Mineral. Petrol., 4.3: 1215-1225.

Perez-Reynoso, J., 1978. Geología y petrografía de la caldera de Los Humeros. Geomimet. 3, 91: 1-40.

Pradal, E. and Robin, C., 1985. Découverte d'unc caldera majeure associée au champ géothermique de Los Azufres (Mexique). C. R. Acad. Sci. Paris, S. 11, 14: 301-316.

Sanchez-Rubio, G., 1978. The Amealco caldera. Geol. Soc. Am., Abstr. with Programs, 10: 145.

Silva-Mora, L., 1979. Contribution a la connaissance de l'Axe volcanique Transmexican: étude géologique et pétrologie des laves du Michoacán oriental. Thése du troisieme cycle, Univ. de Aix-Marseille III, $146 \mathrm{pp}$.

Smith, R.L. and Bailey, R.A., 1968. Resurgent couldrons. Mem. Geol. Soc. Am., 116: 613-622.

Steiger, R.H. and Jäger, E., 1977. Subcommission on geochronology: convention on the use of decay constants in geo- and cosmochronology. Earth Planet. Sci. Lett.. 36: $359-362$.

Suter. M., Mota, R. and Quintero, O., 1989. Active faulting, state of stress, and seismicity in the central part of the Trans- Mexican Volcanic Belt. Bol. Union Geofís. Mex., November: 149 (abstract). 
Tibaldi, A., 1989. The Pleistocene fault pattern of Northern Mi choacàn. Mexico: An example of three-dimensional strain. Ann. Tectonicae. III, 1: 34-43.

Urrutia-Fucugauchi, J. and Bönhel, H., 1988. Tectonics along the Trans-Mexican volcanic belt according to palaeomagnetic data. Phys. Earth Planet. Inter., 52: 320-329.

Venegas, S.S., Maciel, F.R. and Herrera, F.J., 1985. Recursos geotérmicos en la Faja Volcánica Mexicana. In: S.P. Verma (Editor), Special Volume on Mexican Volcanic Belt-Part 1. Geofís. Int., 24: 47-81.
Verma, S.P., 1987. Mexican Volcanic Belt: Present state of knowledge and unsolved problems. In: S.P. Verma (Editor), Special Volume on Mexican Volcanic Belt-Part 3B. Geofís. Int., 26: 309-340.

Verma, S.P., Carrasco-Nun̄ez, G, and Milán, M., 1991. Geology and geochemistry of Amealco caldera, Querétaro, Mexico. J. Volcanol. Geotherm. Res., 47: this issue.

Wilcox, R.E., Harding, T.P. and Seely, D.R., 1973. Basic wrench tectonics. Bull. Am. Assoc. Pet. Geol., 57: 7496. 